\title{
Perbandingan Pemberian Cairan Koloid Co-loading dengan Infus Efedrin terhadap Pencegahan Hipotensi akibat Anestesi Spinal pada Seksio Sesarea
}

\author{
Alifan Wijaya, Dewi Yulianti Bisri, Tatang Bisri \\ Departemen Anestesiologi dan Terapi Intensif \\ Fakultas Kedokteran Universitas Padjadjaran-RSUP Dr. Hasan Sadikin Bandung
}

\begin{abstract}
Abstrak
Latar Belakang: Hipotensi merupakan komplikasi anestesi spinal pada seksio sesarea karena blokade simpatis akibat vasodilatasi arteri dan vena. Pemberian koloid co-loading dapat meningkatkan volume intravaskular sedangkan infus efedrin diharapkan terjadi vasokonstriksi.

Tujuan: Untuk membandingkan pemberian efedrin dan cairan koloid co-loading dalam mencegah hipotensi akibat anestesi spinal pada seksio sesarea.

Metode: Uji terkontrol acak buta tunggal pada 42 pasien seksio sesarea dengan anestesi spinal yang dilakukan di Rumah Sakit Hasan Sadikin Bandung pada September sampai Oktober 2018. Subjek penelitian dibagi secara acak menjadi 2 kelompok yaitu kelompok pemberian infus efedrin dan kelompok pemberian koloid secara co-loading. Kelompok koloid diberikan cairan koloid sebanyak $7 \mathrm{~mL} / \mathrm{KgBB}$ selama 20 menit sedangkan kelompok efedrin diberikan efedrin bolus $5 \mathrm{mg}$ pada menit pertama dan kedua, kemudian $15 \mathrm{mg}$ dalam infus selama 15 menit. Tekanan darah diukur setiap 1 menit selama 10 menit, kemudian setiap 3 menit sampai menit ke-45. Analisis statistik yang digunakan adalah uji T tidak berpasangan dan Mann Whitney.

Hasil: penelitian menunjukan angka kejadian hipotensi lebih sedikit pada kelompok infus efedrin $(5 / 21)$ dibandingkan dengan kelompok koloid $(15 / 21)$ dengan perbedaan yang bermakna $(\mathrm{p}<0,05)$.

Simpulan: penelitian ini menunjukan bahwa kejadian hipotensi pada pasien seksio sesarea yang dilakukan anestesi spinal lebih banyak pada kelompok koloid co-loading dibandingkan dengan kelompok infus efedrin.
\end{abstract}

Kata kunci: anestesi spinal; hipotensi; infus efedrin; koloid co-loading

\section{Comparison of Colloid Co-loading with Ephedrine Infusion on Prevention of Hypotension Due to Spinal Anesthesia in Cesarean Section}

\begin{abstract}
Background: Hypotension is a complication of spinal anesthesia in cesarean section due to sympathetic blockade that causes arterial and venodilation. Administration co-loading of colloid can increase intravascular volume, whereas administration of ephedrine infusion expected to vasoconstric.

Objective: To compare administration of co-loading colloid with ephedrine infusion on preventing hypotension due to spinal anesthesia in cesarean section.

Method: A single blind randomized controlled trial in 42 patients who underwent cesarean section under spinal anesthesia, the physical status of ASA II which was randomly divided into 2 group administering ephedrine infusion and colloid co-loading. Colloid was given $7 \mathrm{ml} / \mathrm{Kg}$ for 20 minutes, whereas ephedrine bolus $5 \mathrm{mg}$ was given in the first and second minutes, then $15 \mathrm{mg}$ in infusion for 15 minutes. Blood pressure is measured every 1 minute for 10 minutes, then every 3 minutes until the 45 th minute. the statistical analysis used is unpaired T test and Mann Whitney. Results: The study showed a lower incidence of hypotension in the ephedrine infusion group $(5 / 21)$ compared with the colloid group $(15 / 21)$, this difference was statistically significant $(p<0.05)$.

Conclusions: This study show that the incidence of hypotension in cesarean section patients was more in the colloid group compared to the ephedrine group.
\end{abstract}

Key words: colloid co-loading; ephedrine infusion; hypotension; spinal anesthesia 


\section{Pendahuluan}

Hipotensi yang terjadi pascaanestesi spinal diakibatkan oleh efek blokade menyeluruh terhadap sistem saraf simpatis sehingga terjadi peningkatan kapasitas vena dan penurunan resistensi vaskular sistemik yang menyebabkan penurunan tekanan darah. ${ }^{1-3}$ Angka kejadian hipotensi yang diakibatkan anestesi spinal lebih tinggi dibandingkan dengan teknik anestesi regional lain. Hipotensi yang terjadi pada seksio sesarea dengan anestesi spinal diperberat oleh perubahan fisiologi jantung pada ibu hamil, penurunan aliran darah balik yang diperburuk oleh kompresi vena kava inferior akibat hipertropi uterus, dan pembentukan sirkulasi kolateral venous plexus di ruang epidural.,5

Pemberian cairan koloid co-loading merupakan salah satu cara yang digunakan dalam pencegahan hipotensi akibat anestesi spinal pada seksio sesarea. ${ }^{5,6}$ Cairan co-loading diberikan dengan tujuan meningkatkan volume vaskular yang diharapkan dapat meringankan efek vasodilatasi akibat anestesi spinal. Pemberian cairan koloid co-loading dapat meningkatkan aliran darah balik vena sehingga terjadi peningkatan curah jantung. ${ }^{7}$ Pemberian cairan koloid co-loading menyebabkan peningkatan volume intravaskular yang cukup untuk mempertahankan aliran darah balik jantung pada perubahan hemodinamik akibat anestesi spinal. ${ }^{8}$ Koloid juga mempunyai berat molekul yang besar dengan aktivitas osmotik yang menyebabkan cairan ini bertahan lebih lama (waktu paruh 3-6 jam) di dalam ruang intravaskular. ${ }^{8}$

Pada penelitian yang dilakukan di India dan Jepang menyebutkan bahwa jumlah koloid yang cukup untuk mencegah hipotensi pascaanestesi spinal pada seksio sesarea adalah sebanyak $7 \mathrm{~mL} /$ $\mathrm{kgBB}$ yang diberikan dalam 20 menit. Penelitian tersebut menyebutkan juga cairan koloid yang diberikan secara co-loading lebih bermanfaat untuk mencegah hipotensi pascaanestesi pada pasien obstetri yang tanpa disertai kelainan. ${ }^{9}$ Efedrin secara umum digunakan dalam anestesi sebagai vasopresor dengan meningkatkan curah jantung dan tahanan vaskular perifer. ${ }^{10}$ Efedrin merupakan agen simpatomimetik nonkatekolamin yang bekerja baik secara langsung maupun tidak langsung merangsang reseptor alpha dan beta adrenergik. Efedrin memiliki sifat agonis indirek dengan melepaskan norepinefrin pascasinaptik atau karena inhibisi penggunaan kembali epinefrin. ${ }^{11,12}$ Obat ini memiliki efek kardiovaskular berupa peningkatan tekanan darah, denyut jantung, dan kontraktilitas jantung. ${ }^{13}$ Penelitian-penelitian sebelumnya telah dilakukan untuk membandingkan efektivitas efedrin yang diberikan antara bolus dan kontinu melalui infus.

Pada penelitian tahun 2016 dinyatakan efedrin yang diberikan secara kontinu memiliki hasil yang lebih baik dibandingkan dengan pemberian bolus dalam mencegah hipotensi. ${ }^{14}$ Pemberian profilaksis efedrin intravena baik dengan infus atau injeksi bolus yang berulang telah dipertimbangkan sebagai gold standard untuk mencegah dan mengobati hipotensi. Namun efek dari bolus efedrin intravena pada arteri hanya bersifat sementara dan hanya berlangsung selama 10-15 menit. ${ }^{5}$ Hasil beberapa penelitian bahwa efedrin $50 \mathrm{mg}$ dalam ringer laktat $500 \mathrm{~mL}$ yang diberikan setelah penyuntikan anestesi spinal dalam kecepatan $50 \mathrm{~mL} /$ menit menunjukan hasil yang baik dalam mencegah hipotensi. Beberapa penelitian menyatakan bahwa infus efedrin lebih efektif dibandingkan dengan pemberian cairan kristaloid pada pasien seksio sesarea yang dilakukan tindakan anestesi spinal. ${ }^{14}$ Penelitian serupa dilakukan di tahun 2016 dengan dosis efedrin yang lebih kecil yaitu $25 \mathrm{mg}$ yang diberikan dalam cairan kristaloid $100 \mathrm{~mL}$ dengan hasil efedrin lebih baik dalam pencegahan hipotensi. ${ }^{5,12}$ Tujuan penelitian ini adalah untuk membandingkan pemberian cairan koloid co-loading dengan infus efedrin terhadap pencegahan hipotensi akibat anestesi spinal pada seksio sesarea. Hasil penelitian ini diharapkan dapat memberi manfaat bagi dokter anestesi dalam pemilihan intervensi untuk mencegah terjadinya komplikasi akibat anestesi spinal pada seksio sesarea.

\section{Metode}

Penelitian ini bersifat eksperimental dengan uji 
acak terkontrol buta tunggal. Subjek penelitian adalah pasien yang menjalani prosedur seksio sesarea dengan anestesi spinal di Rumah Sakit Umum Pusat Dr. Hasan Sadikin Bandung pada bulan Oktober 2018 hingga November 2018. Kriteria inklusi pada penelitian ini adalah pasien dengan status fisik berdasarkan American Society of Anesthesiologists (ASA) kategori II, usia 2040 tahun dan body mass index (BMI) 25-30\% Kriteria eksklusi meliputi pasien yang menolak tindakan anestesi spinal, kehamilan gemeli dan polihidroamnion. Kriteria pengeluaran pada penelitian ini adalah tindakan spinal gagal dan dikonversi ke anestesi umum, perdarahan yang lebih dari $750 \mathrm{~mL}$.

Penelitian ini menggunakan desain analitis kategorik tidak berpasangan dengan penentuan besar sampel uji hipotesis antara dua populasi dari program sample size 2.0 dari Hosmer dan Lemeshow. Jumlah sampel minimal untuk masing-masing kelompok didapatkan 21 orang dan jumlah sampel total sebesar 42 orang pasien. Teknik pemilihan sampel yang digunakan adalah consecutive sampling. Randomisasi subjek penelitian dilakukan dengan menggunakan metode randomisasi blok permutasi. Setelah mendapatkan persetujuan dari Komite Etik Penelitian Kesehatan Rumah Sakit Umum Pusat Dr. Hasan Sadikin Bandung/Fakultas Kedokteran Universitas Padjadjaran No. 640/UN6.C.6.4/ $\mathrm{PP} / 2018$, peserta penelitian yang memenuhi kriteria inklusi dibagi menjadi dua kelompok, kemudian dilakukan informed consent kepada pasien mengenai penelitian yang dilakukan. Sampel dibagi menjadi dua kelompok yaitu kelompok K (Koloid) dan kelompok E (Efedrin).

Pasien yang sesuai kriteria penelitian dilakukan pengelompokan secara acak. Semua pasien yang ikut serta dalam penelitian ini telah dipasang infus dengan Ringer Laktat sebelum masuk ke kamar operasi. Setelah masuk ke kamar operasi, dipasang alat-alat untuk memantau tekanan darah non-invasif, elektrokardiogram dan saturasi oksigen, kemudian diberikan oksigen melalui nasal kanul 3 liter/menit. Sebelum dilakukan tindakan anestesi, pasien dilakukan pemeriksaan tekanan darah untuk mengetahui tekanan darah awal. Anestesi spinal dilakukan pada posisi duduk pada ketinggian L3-L4 menggunakan jarum $25 \mathrm{G}$. Semua pasien menerima jumlah obat yang sama yaitu bupivakain $0,5 \%$ hiperbarik dengan dosis $10 \mathrm{mg}$ dan fentanyl $25 \mathrm{mcg}$, kemudian pasien diposisikan tidur. Ketinggian blok sensoris dinilai dengan tes pinprick dengan target ketinggian blok T6. Setelah dilakukan tindakan anestesi spinal, diberikan cairan koloid gelatin sebanyak $7 \mathrm{~mL} / \mathrm{kgbb}$ dalam 20 menit pada kelompok $\mathrm{K}$ menggunakan infuse pump. Sedangkan untuk kelompok E diberikan efedrin intravena $5 \mathrm{mg}$ pada menit pertama dan $5 \mathrm{mg}$ pada menit kedua, kemudian $1 \mathrm{mg} /$ menit selama 15 menit dalam cairan kristaloid $100 \mathrm{~mL}$ yang diberikan menggunakan infuse pump.

Pencatatan tekanan darah dinilai setelah tindakan anestesi spinal secara non invasif setiap 1 menit dalam 10 menit pertama kemudian setiap 3 menit berikutnya sampai menit ke-45. Bila di kedua grup terjadi penurunan tekanan darah di bawah normal (sistol $<90 \mathrm{mmHg}$ ) maka diberikan rescue dengan pemberian efedrin $5 \mathrm{mg}$ sampai tekanan darah sistol meningkat sampai di atas $90 \mathrm{mmHg}$, bila terjadi denyut jantung di bawah 50x/menit maka akan diberikan sulfas atropin $0,2 \mathrm{mg} / \mathrm{kgBB}$ dan apabila terjadi hipotensi yang menetap diberikan noradrenaline dengan dosis awal $0,05 \mathrm{mcg} / \mathrm{kgBB} / \mathrm{menit}$. Pemberian efedrin rescue dicatat di setiap grup. Oxytocin $10 \mathrm{U}$ diberikan ketika bayi lahir (10 unit dalam $500 \mathrm{~mL}$ Ringer Laktat) pada kedua grup. Untuk analisis statistik data numerik diuji dengan menggunakan uji $\mathrm{T}$ tidak berpasangan apabila data berdistribusi normal serta alternatif Uji Mann Whitney apabila data tidak berdistribusi normal.

\section{Hasil}

Hasil analisis statistik pada 42 subjek penelitian menunjukkan bahwa karakteristik subjek berdasarkan usia, berat badan, tinggi badan, tekanan darah sistol awal dan paritas pada kelompok E maupun kelompok K tidak memiliki perbedaan yang bermakna ( $>00,05$; Tabel 1$)$. Tinggi blokade sensorik pada kelompok E maupun $\mathrm{K}$ tidak ada perbedaan secara statistik ( $>0,05$; Tabel 2). Pada hasil uji perbandingan 
Tabel 1. Perbandingan Karakteristik Umum Pasien Kedua Kelompok Perlakuan

\begin{tabular}{|c|c|c|c|}
\hline \multirow[t]{3}{*}{ Variabel } & \multicolumn{2}{|c|}{ Kelompok } & \multirow[t]{3}{*}{ Nilai $p$} \\
\hline & Efedrin & Koloid & \\
\hline & $\mathrm{N}=21$ & $\mathrm{~N}=21$ & \\
\hline \multicolumn{4}{|l|}{ Usia (tahun } \\
\hline Mean $\pm S t d$ & $29,47 \pm 5,418$ & $30,00 \pm 9,257$ & 0,614 \\
\hline Median & 30,00 & 32,00 & \\
\hline Range (min-max) & $20,00-39,00$ & $20,00-38,00$ & \\
\hline \multicolumn{4}{|l|}{ Berat badan (Kg) } \\
\hline Mean \pm Std & $66,33 \pm 14,67$ & $62,14 \pm 11,105$ & 0,174 \\
\hline Median & 65,00 & 60,00 & \\
\hline Range (min-max) & $52,00-66,00$ & $50,00-65,00$ & \\
\hline \multicolumn{4}{|l|}{ Tinggi badan $(\mathrm{cm})$} \\
\hline Mean $\pm S t d$ & $151,94 \pm 2,90$ & $150,6 \pm 3,47$ & 0,851 \\
\hline Median & 146,00 & 148,00 & \\
\hline Range (min-max) & $150,00-162,00$ & $149,00-162,00$ & \\
\hline \multicolumn{4}{|c|}{$\begin{array}{l}\text { Baseline tekanan darah } \\
\text { sistol }(\mathrm{mmHg})\end{array}$} \\
\hline Mean \pm Std & $121,49 \pm 9,72$ & $120,46 \pm 7,63$ & 0,541 \\
\hline Median & 65,00 & 60,00 & \\
\hline Range (min-max) & $114,00-125,00$ & $115,00-125,00$ & \\
\hline \multicolumn{4}{|l|}{ Paritas } \\
\hline $\mathrm{P} 0$ & $5(23,8 \%)$ & $9(42,9 \%)$ & 0,841 \\
\hline $\mathrm{P} 1$ & $12(57,1 \%)$ & $6(28,6 \%)$ & \\
\hline $\mathrm{P} 2$ & $3(14,3 \%)$ & $5(23,8 \%)$ & \\
\hline $\mathrm{P}>3$ & $1(4,8 \%)$ & $1(4,8 \%)$ & \\
\hline
\end{tabular}

Keterangan : Nilai p diuji dengan uji T tidak berpasangan apabila data berdistribusi normal dengan alternatif uji Mann Whitney apabila data tidak berdistribusi normal..Nilai kemaknaan berdasarkan nilai $p<0,05$.Tanda* menunjukkan nilai $\mathrm{p}<0,05$ artinya signifkan atau bermakna secara statistik

Tabel 2 Perbandingan Tinggi Blokade Sensorik

\begin{tabular}{|c|c|c|c|}
\hline \multirow[t]{2}{*}{ Tinggi Blokade } & \multicolumn{2}{|l|}{ Perlakuan } & \multirow[t]{2}{*}{ Nilai $\mathrm{p}$} \\
\hline & $\begin{array}{l}\text { Efedrin } \\
\mathrm{N}=21\end{array}$ & $\begin{array}{l}\text { Koloid } \\
\mathrm{N}=21\end{array}$ & \\
\hline T6 & $11(52,3 \%)$ & $\begin{array}{l}14 \\
(66,6 \%)\end{array}$ & 1,000 \\
\hline $\mathrm{T} 7$ & $10(47,6 \%)$ & $7(33,3 \%)$ & \\
\hline
\end{tabular}

Keterangan: Untuk data kategorik nilai p dihitung berdasarkan uji statistic Chi-square alternative uji Exact Fisher dan Kolmogorov Smirnov. Nilai kemaknaan berdasarkan nilai $\mathrm{p}<0,05$. Tanda** menunjukkan nilai $\mathrm{p}<0,05$ artinya signifikan atau bermakna secara statistik.

tekanan darah sistol pada 10 menit pertama setelah penyuntikan anestesi spinal didapatkan perbedaan tekanan darah yang bermakna antara kelompok E dan kelompok K pada menit ke-2 sampai ke-8 ( $<<0,05$; Tabel 3). Pada kelompok $\mathrm{K}$ terjadi penurunan tekanan darah di bawah 90 mmHg pada menit ke-2 sampai ke-8. Sedangkan pada kelompok E tekanan darah lebih stabil pada pertama sampai ke-10 (Tabel 3). Tekanan darah sistol pada menit ke-10 sampai ke-45 pada kelompok $\mathrm{E}$ dan kelompok $\mathrm{K}$ tidak terdapat perbedaan tekanan darah antara kedua kelompok ( $>0,05$; Tabel 4).

Kejadian hipotensi lebih banyak terjadi pada kelompok $\mathrm{K}$ dibandingkan dengan kelompok $\mathrm{E}$ dengan perbedaan bermakna $(p<0,05$; Tabel 5). 
Tabel 3. Perbandingan antara Tekanan Darah Sistol Berdasarkan Waktu yang diukur Setiap Menit

\begin{tabular}{|c|c|c|c|}
\hline \multirow[t]{2}{*}{ Tekanan Darah Sistol } & \multicolumn{2}{|l|}{ Kelompok } & \multirow[t]{2}{*}{ Nilai $p$} \\
\hline & $\begin{array}{l}\text { Efedrin } \\
\mathrm{N}=21\end{array}$ & $\begin{array}{l}\text { Koloid } \\
\mathrm{N}=21\end{array}$ & \\
\hline Menit ke-0 (mmHg) & & & 0,830 \\
\hline Mean $\pm \mathrm{Std}$ & $119,76 \pm 6,884$ & & \\
\hline Median & 122,00 & 122,00 & \\
\hline Range (min-max) & $110,00-130,00$ & $107,00-131,00$ & \\
\hline Menit ke-1 (mmHg) & & & 0,122 \\
\hline Mean \pm Std & $111,28 \pm 10,115$ & $109,42 \pm 16,575$ & \\
\hline Median & 110,00 & 110,00 & \\
\hline Range (min-max & $85,00-129,00$ & $77,00-138,00$ & \\
\hline Menit ke-2 (mmHg) & & & $0,009^{*}$ \\
\hline Mean \pm Std & $107,09 \pm 13,758$ & $95,19 \pm 15,233$ & \\
\hline Median & 107,00 & 90,00 & \\
\hline Range (min-max) & $85,00-130,00$ & $78,00-126,00$ & \\
\hline Menit ke-3 (mmHg) & & & $0,004 *$ \\
\hline Mean \pm Std & $109,42 \pm 14,030$ & $94,38 \pm 15,525$ & \\
\hline Median & 112,00 & 88,00 & \\
\hline Range (min-max) & $80,00-132,00$ & $77,00-133,00$ & \\
\hline Menit ke-4 (mmHg) & & & $0,014 *$ \\
\hline Mean \pm Std & $112,28 \pm 12,166$ & $100,38 \pm 17,347$ & \\
\hline Median & 114,00 & 110,00 & \\
\hline Range (min-max) & $89,00-133,00$ & $70,00-133,00$ & \\
\hline Menit ke-5 (mmHg) & & & $0,013 *$ \\
\hline Mean $\pm \mathrm{Std}$ & $113,90 \pm 9,756$ & $103,61 \pm 15,173$ & \\
\hline Median & 115,00 & 110,00 & \\
\hline Range (min-max) & $90,00-128,00$ & $78,00-129,00$ & \\
\hline Menit ke-6 (mmHg) & & & $0,005^{*}$ \\
\hline Mean \pm Std & $114,33 \pm 10,011$ & $99,76 \pm 17,747$ & \\
\hline Median & 118,00 & 91,00 & \\
\hline Range (min-max) & $91,00-128,00$ & $80,00-137,00$ & \\
\hline Menit ke-7 (mmHg) & & & $0,026^{*}$ \\
\hline Mean $\pm \mathrm{Std}$ & $115,33 \pm 11,235$ & $104,09 \pm 18,055$ & \\
\hline Median & 115,00 & 100,00 & \\
\hline Range (min-max) & $92,00-131,00$ & $81,00-137,00$ & \\
\hline \multicolumn{4}{|l|}{ Menit ke-8 (mmHg) } \\
\hline Mean $\pm \mathrm{Std}$ & $115,14 \pm 8,290$ & $110,47 \pm 16,061$ & \\
\hline Median & 117,00 & 108,00 & \\
\hline Range (min-max) & $101,00-131,00$ & $84,00-132,00$ & \\
\hline Menit ke-9 (mmHg) & & & 0,602 \\
\hline Mean $\pm \mathrm{Std}$ & $118,42 \pm 9,410$ & $110,57 \pm 11,209$ & \\
\hline Median & 118,00 & 110,00 & \\
\hline Range (min-max) & $100,00-135,00$ & $92,00-129,00$ & \\
\hline Menit ke-10 (mmHg) & & & 0,650 \\
\hline Mean $\pm \mathrm{Std}$ & $116,85 \pm 7,970$ & $115,66 \pm 8,856$ & \\
\hline Median & 118,00 & 117,00 & \\
\hline Range (min-max) & $100,00-130,00$ & $99,00-131,00$ & \\
\hline
\end{tabular}

Keterangan : Nilai p diuji dengan uji T tidak berpasangan apabila data berdistribusi normal dengan alternatif uji Mann Whitney apabila data tidak berdistribusi normal.Nilai kemaknaan berdasarkan nilai $\mathrm{p}<0,05$. Tanda* menunjukkan nilai $\mathrm{p}<0,05$ artinya signifkan atau bermakna secara statistik. 
Perbandingan Pemberian Cairan Koloid Co-loading dengan Infus

Tabel 4. Perbandingan antara Tekanan Darah Sistol Berdasarkan Waktu yang diukur Setiap 3 Menit

\begin{tabular}{|c|c|c|c|}
\hline \multirow[t]{2}{*}{ Tekanan Darah Sistol } & \multicolumn{2}{|l|}{ Kelompok } & \multirow[t]{2}{*}{ Nilai $\mathrm{p}$} \\
\hline & $\begin{array}{l}\text { Efedrin } \\
\mathrm{N}=21\end{array}$ & $\begin{array}{l}\text { Koloid } \\
\mathrm{N}=21\end{array}$ & \\
\hline Menit ke-13 (mmHg) & & & 0,652 \\
\hline Mean \pm Std & $116,09 \pm 6,556$ & $114,95 \pm 9,452$ & \\
\hline Median & 117,00 & 113,00 & \\
\hline Range (min-max) & $100,00-125,00$ & $99,00-128,00$ & \\
\hline Menit ke-16 (mmHg) & & & 0,659 \\
\hline Mean \pm Std & $117,09 \pm 7,077$ & $117,52 \pm 8,441$ & \\
\hline Median & 119,00 & 120,00 & \\
\hline Range (min-max) & $102,00-127,00$ & $101,00-128,00$ & \\
\hline Menit ke-19 (mmHg) & & & 0,737 \\
\hline Mean \pm Std & $115,80 \pm 7,096$ & $114,85 \pm 10,734$ & \\
\hline Median & 116,00 & 118,00 & \\
\hline Range (min-max) & $98,00-128,00$ & $92,00-128,00$ & \\
\hline Menit ke-22 (mmHg) & & & 0,775 \\
\hline Mean \pm Std & $116,85 \pm 7,780$ & $116,04 \pm 10,312$ & \\
\hline Median & 118,00 & 118,00 & \\
\hline Range (min-max) & $101,00-131,00$ & $98,00-131,00$ & \\
\hline Menit ke-25 (mmHg) & & & 0,886 \\
\hline Mean \pm Std & $115,85 \pm 7,989$ & $115,42 \pm 11,029$ & \\
\hline Median & 118,00 & 118,00 & \\
\hline Range (min-max) & $100,00-132,00$ & $92,00-132,00$ & \\
\hline Menit ke-28 (mmHg) & & & 0,554 \\
\hline Mean \pm Std & $117,47 \pm 8,041$ & $115,14 \pm 10,532$ & \\
\hline Median & 118,00 & 111,00 & \\
\hline Range (min-max) & $104,00-134,00$ & $98,00-128,00$ & \\
\hline Menit ke-31 (mmHg) & & & 0,910 \\
\hline Mean \pm Std & $116,95 \pm 9,552$ & $116,80 \pm 11,249$ & \\
\hline Median & 116,00 & 120,00 & \\
\hline Range (min-max) & $101,00-132,00$ & $90,00-130,00$ & \\
\hline Menit ke-34 (mmHg) & & & 0,784 \\
\hline Mean \pm Std & $116,04 \pm 9,457$ & $116,90 \pm 10,643$ & \\
\hline Median & $100,00-133,00$ & $98,00-130,00$ & \\
\hline Menit ke-37 (mmHg) & & & 0,795 \\
\hline Mean \pm Std & $116,90 \pm 7,822$ & $110,47 \pm 16,061$ & \\
\hline Median & 120,00 & 121,00 & \\
\hline Range (min-max) & $102,00-129,00$ & $94,00-132,00$ & \\
\hline Menit ke-40 (mmHg) & & & 0,722 \\
\hline Mean \pm Std & $116,71 \pm 7,629$ & $110,57 \pm 11,209$ & \\
\hline Median & 118,00 & 116,00 & \\
\hline Range (min-max) & $106,00-130,00$ & $98,00-132,00$ & \\
\hline Menit ke-43 (mmHg) & & & 0,987 \\
\hline Mean \pm Std & $117,42 \pm 8,669$ & $115,66 \pm 8,856$ & \\
\hline Median & 115,00 & 120,00 & \\
\hline Range (min-max) & $104,00-132,00$ & $102,00-135,00$ & \\
\hline Menit ke-45 (mmHg) & & & 0,573 \\
\hline Mean \pm Std & $118,14 \pm 5,755$ & & \\
\hline Median & 120,00 & 122,00 & \\
\hline Range (min-max) & $109,00-128,00$ & $100,00-135,00$ & \\
\hline
\end{tabular}

Keterangan: Nilai $\mathrm{p}$ diuji dengan uji T tidak berpasangan apabila data berdistribusi normal dengan alternatif uji Mann Whitney apabila data tidak berdistribusi normal. Nilai kemaknaan berdasarkan nilai $\mathrm{p}<0,05$.Tanda* menunjukkan nilai $\mathrm{p}<0,05$ artinya signifkan atau bermakna secara statistik. 
Tabel 5. Perbandingan Kejadian Hipotensi dan Penggunaan Efedrin sebagai Rescue

\begin{tabular}{lllll}
\hline Variabel & \multicolumn{2}{l}{ Kelompok } & OR(CI 95\%) & Nilai P \\
\cline { 2 - 3 } & $\begin{array}{l}\text { Efedrin } \\
\mathrm{N}=21\end{array}$ & $\begin{array}{l}\text { Koloid } \\
\mathrm{N}=21\end{array}$ & & \\
\hline Hipotensi & & & $8.00(2.012-31.803)$ & 0.002 \\
Tidak & 16 & 6 & & \\
Ya & 5 & 15 & & 0,002 \\
$\begin{array}{l}\text { Efedrin Rescue } \\
\text { (orang) }\end{array}$ & 5 & 15 & & \\
\hline
\end{tabular}

Keterangan : Untuk Data kategorik nilai p dihitung berdasarkan uji Chi-Square dengan alternative uji Kolmogorov Smirnov dan Exact Fisher apabila syarat dari Chi-Square tidak terpenuhi.Nilai kemaknaan berdasarkan nilai $\mathrm{p}<0,05$.Tanda* menunjukkan nilai $\mathrm{p}<0,05$ artinya signifkan atau bermakna secara statistik.

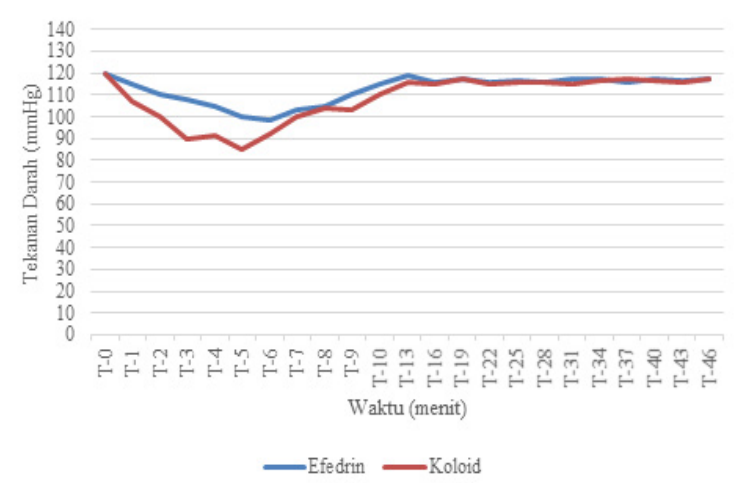

Grafik 1. Tekanan Darah Sistol Tiap Menit

Perbandingan penggunaan efedrin sebagai rescue pada kedua kelompok menunjukan kelompok $\mathrm{K}$ lebih banyak diberikan efedrin sebagai rescue dibandingkan E $(\mathrm{p}<0,05$; Tabel 5). Gambaran tekanan darah sistol selama 45 menit pada kedua kelompok terlihat bahwa pada kelompok $\mathrm{K}$ penurunan tekanan darah terjadi pada 10 menit pertama sedangkan kelompok E tekanan darah sistol lebih stabil. Tekanan darah sistol pada kedua kelompok pada 10 menit selanjutnya relatif stabil (Gambar 1).

\section{Pembahasan}

Pada penelitian ini tekanan darah sistol kelompok E lebih stabil secara statistik dibandingkan kelompok K. Pada kelompok K terjadi penurunan tekanan darah sistol yang lebih besar pada menit ke-2 sampai ke-8 (Tabel 3). Angka kejadian hipotensi lebih banyak terjadi pada grup $\mathrm{K}$ dibandingkan dengan grup $\mathrm{E}(\mathrm{p}<0,005$; Tabel 5).
Jumlah penggunaan efedrin sebagai rescue pada kedua kelompok sesuai dengan angka kejadian hipotensi, kelompok E sebanyak 5 dari 21 orang sedangkan kelompok K sebanyak 15 dari 21 orang. Pemberian cairan merupakan metode nonfarmakologis yang sering digunakan pada pencegahan hipotensi. Pada beberapa penelitian menunjukan hasil yang cukup baik dalam mencegah hipotensi dan telah rutin menjadi pilihan. Bagaimana pun keberhasilan teknik ini telah dipertanyakan pada beberapa penelitian lain yang telah dilakukan menunjukan teknik ini mempunyai keterbatasan dalam mencegah hipotensi, salah satunya rute pemberian cairan dan jumlah pemberian yang diberikan. Pada penelitian sebelumnya disebutkan bahwa kejadian hipotensi tetap ada walaupun diberikan cairan jumlah besar yang diakibatkan oleh kontraksi uterus yang terjadi terus-menerus. Setiap kontraksi uterus darah yang dipompakan ke sirkulasi maternal sekitar $300 \mathrm{~mL}$. Perkembangan janin terutama bertambahnya ukuran kepala akan menekan caval sehingga terjadi penekanan aortocaval. Setiap kontraksi uterus menambah penekanan pada aortocaval sehingga hipotensi semakin lebih besar. Pada penelitian tersebut disebutkan bahwa teknik yang dapat mengurangi kejadian hipotensi adalah pemberian cairan disertai posisi pasien miring ke arah kiri untuk mengurangi penekanan aortocaval. ${ }^{18}$

Pemberian cairan koloid merupakan alternatif pencegahan hipotensi pascaanestesi spinal. Cairan ini berada di pembuluh darah untuk waktu yang 
lebih lama bila dibandingkan dengan kristaloid. Pada penelitian sebelumnya disebutkan bahwa cairan koloid yang cukup untuk mencegah hipotensi adalah $7 \mathrm{~mL} / \mathrm{KgBB}$ selama 20 menit.

Pada penelitian ini pemberian koloid tidak berhasil mencegah hipotensi yang dipengaruhi beberapa faktor, yaitu jumlah cairan yang tidak cukup dan penekanan pada aortocaval. Jumlah cairan koloid yang diberikan pada penelitian ini tidak mencukupi untuk mengimbangi efek vasodilatasi yang terjadi segera setelah penyuntikan obat spinal sehingga hipotensi tetap terjadi.

Lokasi kerja obat anestesi spinal adalah di akar saraf. Agen anestesi lokal yang diinjeksikan ke cairan serebrospinal akan merendam akar saraf di ruang subarachnoid. Blokade terhadap tranmisi saraf di dalam posterior akan memutuskan sensasi somatik dan viseral, sedangkan blokade pada serabut saraf bagian anterior mencegah aliran saraf eferen motorik dan otonom. ${ }^{7,8}$ Anestesi lokal bupivakain hiperbarik mempunyai onset yang cepat 2 menit setelah penyuntikan dan durasi yang panjang (90-120 menit). Waktu maksimal obat menyebar ke arah cephalad 5-30 menit. ${ }^{9}$ Fixation time merupakan waktu yang diperlukan oleh obat anestesi lokal untuk menetap pada level tertentu yang terjadi pada 15-20 menit pertama. Setelah tekanan darah mencapai tingkat terendah, tekanan darah sistol seringkali meningkat secara spontan $5-10 \mathrm{mmHg}$ pada $10-15$ menit berikutnya sebagai manifestasi aktivitas kompensasi sirkulasi oleh saraf simpatis yang tidak mengalami blokade dan juga oleh kembalinya sebagian kecil tonus otot polos pada vaskularisasi perifer yang mengalami denervasi.

Tekanan darah kemudian stabil dan relatif menetap sampai efek anestesi lokal habis. ${ }^{7-9}$ Pada penelitian ini perbedaan tekanan darah yang bermakna terjadi pada menit ke-2 sampai dengan ke-8. Tekanan darah setelah menit ke-10 pada kedua kelompok lebih stabil dan tidak ada perbedaan. Hal ini dapat disebabkan anestesi lokal yang disuntikan sudah mencapai onset pada menit ke-2. Setelah menit ke-10 tekanan darah kedua kelompok tidak ada perbedaan karena volume intravaskular sudah terisi pada kelompok K. Efedrin mempunyai onset pada pembuluh darah selama 90 detik setelah penyuntikan intravena. ${ }^{8}$ Onset efedrin terjadi lebih dahulu dari onset blokade spinal sehingga mencegah vasodilatasi dan tidak terjadi hipotensi setelah penyuntikan intravena. Pemberian efedrin setelah tindakan anestesi spinal dapat mempertahankan tekanan darah dengan meningkatkan cardiac output dan denyut jantung sesuai mekanisme kerja utama dari efedrin yang utamanya secara indirect dengan menstimulasi pelepasan norefinefrin dari ujung saraf simpatis yang menyebabkan vasokonstriksi pembuluh darah dan meningkatkan kontraktilitas miokardial sehingga terjadi peningkatan tekanan darah sistol, diastol, laju nadi dan cardiac output sehingga tekanan darah stabil. ${ }^{8}$

Penggunaan infus efedrin memiliki kontrol lebih baik pada arterial pressure karena vasodilatasi akibat anestesi spinal terjadi pada arteri dan vena. Pemberian infus efedrin yang kontinu membuat pembuluh darah arteri akan tetap konstan sehingga hipotensi tidak terjadi. Angka kejadian hipotensi pada kelompok efedrin dapat berkurang karena ketika terjadi vasodilatasi pada pembuluh darah, efek efedrin mempertahankan tekanan darah dengan meningkatkan cardiac output dan denyut jantung sehingga tekanan darah lebih stabil dibandingkan dengan pemberian cairan co-loading. Pada penelitian ini perbandingan cairan koloid co-loading dengan efedrin tidak sebanding karena pada saat terjadi vasodilatasi, cairan koloid yang dibutuhkan tidak cukup untuk mempertahankan tekanan darah sedangkan pada pemberian efedrin hanya membutuhkan waktu 90 detik untuk terjadi vasokonstriksi.

Pada penelitan sebelumnya tahun 2016 membandingkan pemberian infus efedrin sebanyak $25 \mathrm{mg}$ dengan pemberian cairan kristaloid pada pasien seksio sesarea yang dilakukan anestesi spinal. Hasil dari penelitian tersebut didapatkan angka kejadian hipotensi lebih banyak pada kelompok kristaloid (48\%) dibandingkan dengan kelompok infus efedrin (24\%) dengan perbedaan bermakna $(p<0,05)$, sedangkan pada penelitian ini angka kejadian hipotensi pada kelompok koloid 71,4\% dan kelompok efedrin $23,8 \%$. Perbedaan ini terjadi karena jenis cairan, cara pemberian, dan 
jumlah cairan yang digunakan berbeda. Efedrin yang diberikan intravena secara profilaksis dengan infus maupun bolus dipertimbangkan menjadi gold standard untuk menghindari dan mengobati hipotensi. Efedrin merupakan sintetis simpatomimetik yang menstimulasi pelepasan reseptor adrenergik $\alpha$-dan $\beta$-pada adrenoreceptor. Endositosis efedrin masuk ke dalam adrenergik $\alpha$ - dan $\beta$ - pada ujung terminal postganglion presinaptik menggantikan norefinefrin pada aliran sinaptik. Aktivasi ini menyebabkan vasokonstriksi pembuluh darah dan meningkatkan kontraktilitas miokardial sehingga terjadi peningkatan tekanan darah sistol, diastol, laju nadi dan cardiac output. ${ }^{6,7}$ Selain itu juga, peningkatan denyut jantung, dan kontraktilitas jantung. ${ }^{5}$ Pada arteri terjadi vasokontriksi sementara dan hanya terjadi pada $10-15$ menit. $^{19}$

\section{Simpulan}

Pemberian infus efedrin secara kontinu yang diberikan setelah tindakan anestesi spinal lebih baik dibandingkan dengan pemberian cairan koloid co-loading dalam mencegah hipotensi pada tindakan anestesi spinal pada seksio sesarea. Hal ini menunjukan bahwa derajat hipotensi yang dicegah oleh pemberian efedrin kontinu secara statistik lebih baik dibandingkan dengan pemberian cairan koloid co-loading.

\section{Daftar Pustaka}

1. Cyna AM, Andrew M, Emmett RS, Middleton P, Simmons SW. Techniques for preventing hypotension during spinal anaesthesia for caesarean section. The Cochrane Library. 2006;12-7.

2. McDonnell N, Paech M, Clavisi O, Scott K, Group AT. Difficult and failled intubation in obstetric anaesthesia: an observational study of airway management and complications associated with general anaesthesia for caesarean section. Int $\mathrm{J}$ of Obst Anesth. 2008;17(4):292-7.

3. Joy LH, James FA, Brenda AB, Richard TC,
Patricia AD. Practice guidelines for obstetric anesthesia: an updated report by the American Society of Anesthesiologists Task Force on Obstetric Anesthesia. 2007;106(4):843.

4. Campbell J, Sultan P. Regional anaesthesia for caesarean section: a choice of three techniques. Br J Hosp Med. 2009;70(10):605.

5. Ahmed HO, Hossam M, Adel A. Volume preload versus ephedrine infusion for prevention of hypotension due to spinal anesthesia for cesarean section. Open $\mathrm{J}$ of Anest. 2016;6(03):37.

6. Tamilselvan P, Fernando R, Bray J, Sodhi M, Columb M. The effects of crystalloid and colloid preload on cardiac output in the parturient undergoing planned cesarean delivery under spinal anesthesia: arandomized trial. Anest \& Analg. 2009;109(6):1916-21.

7. Fornich MA. Obstetric anesthesia. Dalam: Butterworth JF, Mackey DC, Wasnick JD, penyunting. Morgan and Mikhail's Clinical Anesthesiology. Edisi ke-5. New York: McGraw-Hill Company; 2013. 848-56.

8. Braveman FR, Scavone BM, Bleesing ME, Wong CA. Obstetric anaesthesia. Dalam: Barash PG, Cullen BF, Stoelting RK, Cahalan MK, Stock MC, penyunting. Clinical Anesthesia. Edisi ke-8. Philadelphia: Lippincott Williams \& Wilkins; 2017. Hlm. 2841-9.

9. Whiteside JB, Wildsmith JAW. Spinal anaesthesia: an update. Critical Care \& Pain; 2005;5:39.

10. Jabalameli M, Soltani HA, Behdad S, Soleimani B, Bahram S. Prevention of post-spinal hypotension using crystalloid, colloid and ephedrine with three different combinations: a double blind randomized study. Adv biomed res; 2012;1:36.

11. Iqbal MS, Ishaq M, Masood A, Zafar K M. Optimal dose of prophylactic ephedrine for 
spinal-induced hypotension during caesarean section. Anest Pain \& In Care. 2010;14(2): $71-5$.

12. Ngan Kee WD, Khaw KS, Lee BB, Lau K, Gin T. A dose response study of prophylactic intravenous ephedrine for prevention of hypotension during spinal anesthesia for cesarean delivery. Anesth Analg 2000;90:1390-5.

13. Koichi N, Naho Y, Shigeru S. Comparison of effects of rapid colloid loading before and after spinal anesthesia on maternal hemodynamics and neonatal outcomes in caesarean section. J of Clin Monit and Comp 2007; 21:125-9.

14. Kinsela SM, Carvalho B, Dryer A, Fernando $\mathrm{R}$, McDonnel N, Mercier FJ. International consensus statement on management of hypotension with vasopressors during caesarean section under spinal anaesthesia. The Association of Anaesthetists of Great Britain and Ireland. 2017;73:71-92.

15. Langesæter E, Dyer RA. Maternal haemodynamic changes during spinal anaesthesia for caesarean section. Curr Op in Anest. 2011;24(3): 242-8.

16. Roofthooft E, Van de Velde M. Low-dose spinal anaesthesia for caesarean section to prevent spinal-induced hypotension. Curr Op in Anest. 2008; 21(3):259-62.

17. Ioannidis R, Stachtari C, Koraki E, Chatzopoulos S, Trikoupi A, Ketikidou E. Impact of height on spinal anesthesia for elective caesarean section: a retrospective study. Greek E-J of Periop Med 2018;17:1525 .

18. Vercauteren M, Hoffmann V, Coppejans C, Steenberge V, Adriaensen H. Hydroxyethylstarch compared with modiefied gelatin as volume preload before spinal anaesthesia for caesarean section. $\mathrm{Br} \mathrm{J}$ of Anaesth 1996; 76:731-3.

19. Bhovi M, Shridev AS, Rao V. A comparative study of ephedrine infusion with the coload of crystalloids for prevention of hypotension during spinal anaesthesia for elevtive caesarean section. Ind J of App Res 2014;4: 2249-5. 